\title{
DIRECTION OF CAUSALITY BETWEEN FINANCIAL DEVELOPMENT AND ECONOMIC GROWTH. EVIDENCE FOR DEVELOPING COUNTRIES
}

\author{
Borlea Sorin Nicolae PhD. \\ „Vasile Goldis” Western University of Arad \\ E-mail: snborlea@yahoo.com \\ Mare Codruta PhD \\ Babes-Bolyai University of Cluj-Napoca \\ E-mail: codruta.mare@econ.ubbcluj.ro \\ Achim Monica Violeta PhD \\ Babes-Bolyai University of Cluj-Napoca \\ E-mail: monica.achim@econ.ubbcluj.ro \\ Puscas Adriana PhD \\ „Vasile Goldis” Western University of Arad \\ E-mail: adriana.puscas@yahoo.com
}

(Received March 2016; Accepted May 2016)

\begin{abstract}
The results of extensive studies that analyzed the existence and meaning of correlations between the economic growth and the financial market development lead us to a more thorough study of these correlations. Therefore, we performed a broad study of the developing countries from around the world (the developing part of each region constructed by the World Bank through its Statistics Bureau). The regions taken into analysis were: Europe and Central Asia, South Asia, East Asia and the Pacific, the Arab world, Latin America \& and the Caribbean, the Middle East and North Africa, and Sub-Saharan Africa. For comparison purposes, we have also included in the sample the North American countries, the Euro Area and the European Union as a whole, because these last three areas are the main benchmarks of the financial markets. The results are consistent with those from previous studies on the subject and vary depending on region and financial indicator considered.
\end{abstract}

Keywords: capital market development, economic growth, correlations, time-series JEL classification: F43, G14, G15

\section{Introduction}

Economic growth is a complex process that is influenced by several factors, other than the capital market development. For instance, Dumiter \& Todor (2014), in theirs study conducted in Central and Eastern European countries, find that foreign direct investments bring an essential contribution to the economic growth, creating work places, optimize the allocation of resources, enabling technology transfer and stimulate trading. Moreover, capital market development is the result of many 
Borlea S.N., Mare C., Achim M.V., Puscas A. (2016)

Direction of causality between financial development and economic growth. Evidence for developing countries

factors. Because there are several interdependencies between these factors, documenting a clear relationship between the economic growth and the capital market development is difficult. In this paper, we intend to respond to the following questions: what is the significance of the correlation between the economic development and the financial development of a country? Is the degree of financial development a cause and effect for the actual economic development of a country? The answers to these questions are very useful, first, for grounding the economic growth governmental policies of a country and second, for any investors in financial markets.

The connection between capital market development and economic growth has received much attention throughout the years. The long-run correlation between the level of financial development and economic performance is generally recognized and accepted (Goldsmith, 1969; King and Levine, 1993).

The origin of this type of investigations is found in the research conducted by Schumpeter (1934). He argues that financial intermediaries are important for innovation and development. According to Schumpeter, to explaining economic change by previous economic conditions alone is impossible. The economic state of a people emerges from all of the situations that preceded them. One of the tools used by economists in order to explain the economic changes consists of the financial systems of countries. The relationship between financial structure and development is investigated in various studies and the results of the studies lead to diverse conclusions, as presented below: financial development and economic growth are not causally related (Chang 2002, Acaravci et al. 2007); Financial development follows economic growth (Liang \& Teng 2006; Brasoveanu et al. 2008,); Financial development is a cause of economic growth (Van Nieuwerburgh et al. 2006, Rousseau \& Wachtel $(2009,2011)$; financial development is an impediment to economic growth (Stiglitz 2002, Caporale et al (2009).

Bearing in mind that the majority of the studies were made on developed countries or regions, we have chosen to analyze only the developing countries. Thus, our study aims to clarify which is the type of relationship between different indicators of the financial market and the economic development for the developing countries belonging to Europe and Central Asia, South Asia, East Asia and Pacific, The Arab World, Latin America \& Caribbean, Middle East and North Africa, Sub-Saharan Africa. For comparison reasons, we have also included in the sample the North American countries, the Euro Area and the European Union as a whole, as they are the main benchmarks of the financial markets. Annual data was considered for this analysis, in the period $1988-2011$ and they are provided by World Development Indicators (World Bank 2012). To assess the relationships we have employed time 
Borlea S.N., Mare C., Achim M.V., Puscas A. (2016)

Direction of causality between financial development and economic growth. Evidence for developing countries

series analysis methods in which correlation coefficient analysis along with the Granger causality analysis are used.

Our paper is structured as follows. In the next section 2, the literature review on the correlation between financial economic and economic growth are designed. In section 3, we designed methodology and data sources. Further section 4 includes the results of our study and proper discussions on these. The paper ends with the main conclusions including some limits of the research and also the policy implications of our study.

\section{Literature review}

Investigating a vast literature in the field, we find several interdependencies between these factors, which makes it difficult to establish and isolate the causal relation between the economic growth and the capital market development.

A first category of studies document that financial development and economic growth are not causally related. An example of this type of relationship is found in the early modern economy of Europe, in the 17th Century. Graff (1999) suggests that the finance--growth nexus might be less relevant for industrialized countries with already highly developed financial systems. In Turkey, Acaravci et al. (2007) found no long-run relationship between financial development and economic growth. Chang (2002) found independence between financial development and economic growth for Mainland China.

A second strand in literature points out that financial development follows economic growth. Hanousek \& Filer (1997) determined that, among ex-communist countries (The Czech Republic, Hungary, Poland and Slovakia), the Czech equity market is characterized by semi-strong efficiency. However, while for the other three, changes in the real economy affect the stock exchange parameters with a lag of 1 ; therefore, they do not present this form of efficiency, and there is sufficient space for opportunity.

Filer et al. (2000) document the efficient markets hypothesis in developed countries. In their study conducted in 70 countries, they found that, particularly in developed countries, the capital markets include the future growth rates in current prices. Chung \& Tai (1999) and Liang \& Teng (2006) in their studies conducted for Asian countries (Korea, Taiwan, Singapore, Hong Kong, Malaysia, and China), found "the economic role of the stocks markets, which responds to changes in its fundamental economic variables".

For the emerging economies, the results of El-Wassal (2005) confirm that economic growth, financial liberalization policies and foreign portfolio investments were the leading factors of the emerging stock markets growth. These results seem to validate the demand-following hypothesis, suggesting that economic growth has 
Borlea S.N., Mare C., Achim M.V., Puscas A. (2016)

Direction of causality between financial development and economic growth. Evidence for developing countries

indeed activated stock markets in these countries. The results that Brasoveanu et al. (2008) obtained for Romania (another emerging economy), consisted of a feedback effect between capital - market trade volume and economic growth, but the strongest connection is found from economic growth to capital markets. With respect to developing economies, Kar \& Pentecost (2000) found the same correlation for Turkey, that is, unidirectional causality, which is from economic growth to financial development. By conducting a survey on 13 sub-Saharan African countries, Ghirmay (2004) determined that economic growth causes financial development in nine countries. For the USA, Beck, Lundberg and Majnoni (2006) also found a positive correlation between capital market development (measured by a dummy variable computed to reflect whether the market capitalization exceeds $13.5 \%$ of GDP and economic growth). Conducting a large investigation in the financial literature, Garretsen et al. (2004) found a causal relationship between economic growth and financial market development; a $1 \%$ improvement in economic growth determines a $0.4 \%$ rise of market capitalization / GDP ratio.

A large strand in literature document that financial development is a cause of economic growth. Complex studies show a robust correlation between financial factors and economic growth that is consistent with a leading role for finance. Mature financial systems can cause high and sustained rates of economic growth. Among these studies, we can mention some of the most representative ones considering the territorial extensiveness of the performed studies, which include the following: Atje \& Jovanovic (1993) for 72 countries, King \& Levine (1993) for 80 countries, Rajan \& Zingales (1998) for a large sample of countries, Graff (1999) for 93 countries, Beck \& Levine (2004) for 40 countries, Arestis et. al. (2001) for six developing countries, Seetanah et al. (2009) for 20 island economies, and Boubakari \& Jin (2010) for 5 Euronext countries, Wong \& Zhou (2011) for 5 welldeveloped countries. Studies on a smaller scale territory show the influence of the degree of development of the financial system of a country over its economic system. Examining a long survey period (200 years) in Belgium, Nieuwerburgh et al. (2006) found that stock market development determined economic growth, particularly in the period 1873--1935, but also on over the entire analyzed period $(1800-2000)$, with variations in time due to institutional changes affecting the stock exchange.

For Turkey, the results of the studies made by Aslan \& Kucukaksoy (2006) and Acaravci et al. (2007) indicate that financial development leads to economic growth. Studying 13 sub-Saharan African countries, Ghirmay (2004) found that financial development causes economic growth in eight countries. In addition, for poor countries in West Africa, Herve \& Shen (2011) he noticed that stock market 
Borlea S.N., Mare C., Achim M.V., Puscas A. (2016)

Direction of causality between financial development and economic growth. Evidence for developing countries

development is an important ingredient for growth in the West African monetary Union because the stock market provides a general idea of an economy's health. Zivengwa et al. (2011) performing a survey on Zimbabwe (South Africa's country), also found a uni-directional causal link that runs from stock market development to economic growth. Moreover there is evidence of an indirect transmission mechanism through the effect of stock market development on investment. Conversely, the result of Mun et al. (2008) revealed that in Malaysia, one of the more highly developed countries of South-Eastern Asia, the stock market does help predict the future economic health.

In their studies, which were conducted on 80 countries, Rousseau \& Wachtel (2009, 2011) concluded that in richer countries, the highly developed intermediaries and market-based private sector institutions are more important than in poorer countries. For all countries, the direction of causality is from the financial system to the real economy (reflected by GDP), and any no contrary evidence is found. Later, Rousseau \& Wachtel $(2009,2011)$ found specific conclusions that were adapted to the current context of the current financial crisis. In the actual context of finance, although the finance-growth relationship is largely documented in the empirical literature, the authors show that the relationship is not as strong in more- recent data as it was in the original studies of the period 1960- -1989 . According to the authors Rousseau \& Wachtel $(2009,2011)$ the financial crises's effect is related to "the dampening of the effect of financial deepening on growth". Another category of studies find that financial development is an impediment to economic growth. Performing a large literature review, Stiglitz (2002) concludes that, similar to the previous possibility, causality runs from financial development to real development. The author highlights the potential destructive and destabilizing role and of a financial system. Performing a survey on a sample of 11 Arab countries, Naceur et al. (2008) concluded that underdeveloped financial systems negatively influence the economic growth in these countries and stress the role of building a strength financial system for them. In their study in the field of finance-growth nexuses conducted in ten New European Union members, Caporale et al. (2009) ascertained the existence of a reduced financial development; and therefore, the contribution of the relatively underdeveloped credit and stock markets to growth is limited. For 81 provinces of Turkey, Ardic \& Damar (2006) found a strong negative relationship between financial deepening and economic growth.

A last category of the studies documents that the relationship between economic growth and capital market development is bi-directional. A significant number of studies focusing on the causality between finance-growth nexuses, identified the existence of a bi-directional relationship between the two parameters. Thus, a great 
Borlea S.N., Mare C., Achim M.V., Puscas A. (2016)

Direction of causality between financial development and economic growth. Evidence for developing countries

number of studies made in the most- developed countries, the United States, the UK, Germany, and Japan (Fama 1991, Pearce \& Roley 1988) confirm a good synchronization and strong correlation between these two parameter sets. Granger causality tests indicate that there is a bi-directional relationship between stock market growth indicators and real economic activity, privatization, and stock returns for the most of the developed countries. Moreover, for 109 developing and industrial countries, Calderón \& Liu (2003), the result of study showed also a bidirectional relationship between financial development and economic growth. Unalmis (2002) and later Demirhan et al. (2011) remarked on long-run bidirectional causality in Turkey (another emerging country), between financial development and economic growth. Performing a survey on Greece, another emerging country, Hondroyiannis et al. (2004) determined that the relationship between economic growth and capital market development is bi-directional. Studying 13 sub-Saharan African countries, Ghirmay (2004) also found also $a$ bidirectional causal relationships exist in six countries. For Romania, Brasoveanu et al. (2008) feedback effect between capital- market trade volume and economic growth, but the strongest correlation is from economic growth to capital markets. This result suggests that the financial development follows economic growth; therefore, economic growth drives financial institutions to change and develop. By performing a large investigation in this field (over 70 studies in the area of correlations between the economic development and financial development) and, by considering the classification of the countries included in the study, we obtain the following results:

Table 1. The correlation financial-growth nexus, based on the literature review

\begin{tabular}{|l|c|c|c|}
\hline \multicolumn{1}{|c|}{ Type of correlation } & \multicolumn{2}{|c|}{ Number of studies (as \% in total) } \\
\cline { 2 - 4 } & $\begin{array}{c}\text { Developed } \\
\text { countries }\end{array}$ & $\begin{array}{c}\text { Developing } \\
\text { countries }\end{array}$ & $\begin{array}{c}\text { Total } \\
\text { countries }\end{array}$ \\
\hline $\begin{array}{l}\text { 1. Financial development and economic growth are not causally } \\
\text { related }\end{array}$ & $4 \%$ & $1 \%$ & $5 \%$ \\
\hline 2. Financial development follows economic growth & $10 \%$ & $11 \%$ & $21 \%$ \\
\hline 3. Financial development is a cause of economic growth & $20 \%$ & $30 \%$ & $50 \%$ \\
\hline 4. Financial development is an impediment to economic growth & $1 \%$ & $5 \%$ & $6 \%$ \\
\hline $\begin{array}{l}\text { 5. The relationship between economic growth and capital market } \\
\text { development is bi-directional: }\end{array}$ & $11 \%$ & $8 \%$ & $19 \%$ \\
\hline
\end{tabular}

Source: own calculations based on over 70 studies referring on correlation finance-growth nexus

Note that in half of the studies, a positive effect of financial development on economic growth was identified; that is, the degree of financial development is a factor in the economic development of a country. This positive effect is found more often for developing countries $(30 \%)$ than for developed countries $(20 \%)$.

6 DE GRUYTER OPEN 
Borlea S.N., Mare C., Achim M.V., Puscas A. (2016)

Direction of causality between financial development and economic growth. Evidence for developing countries

Approximately $21 \%$ of the results show a causality relationship from the economic development toward the financial development. In this case, the results do not seem to be differentiated according to the categories of developing or developed countries. In $19 \%$ of the studies, a bi-directional correlation is identified, showing the complexity of the causal relationships between the two variables. Notice that this bi-directional correlation is highly present in both categories of countries (developed and developing). However, several studies indicate a slight orientation toward developed countries. In $6 \%$ of the studies, financial development is an impediment to economic growth, which is more of a characteristic of developing countries. Financial development could negatively influence the economic growth in countries with underdeveloped financial systems.

The variables used in these studies can be grouped in the following categories:

1. Economic growth variables expressed by: Gross Domestic Product (GDP) in current USD (Mun et al.2008, Boubakari et al. 2010, Demirhan et al. 2011; logarithm of real GDP (Arestis, Demetriades \& Luintel 2001; GDP growth rate (Baier, Dwyer Jr. \& Tamura 2004, Wong \& Zhou 2011; GDP per capita growth rate (King \& Levine 1993), Seetanah et al. 2009; Initial real GDP per capita (Wachtel 2001, Yay \& Oktayer 2009; Investment (Levine \& Zervos 1996, Zivengwa et al. 2011, Boubakari et. al. 2010; International trade (or export), Beck \& Levine 2004; Beck, Lundberg \& Majnoni 2006.

2. Capital market variables expressed by: a) Size variables: Total market capitalization (Brasoveanu et al. 2008, Boubakari et. al 2010, Demirhan et al. 2011, Wong et al. (2011); Market capitalization / GDP ratio (King, Levine 1993, Levine \& Zervos 1996, Rousseau \& Wachtel 2009,2011, Caporale et. al 2005,2009, Van Nieuwerburgh et al. 2005, Zivengwa et al. 2011, Herve \& Shen 2011; The logarithm of the stock market capitalization ratio (Arestis, Demetriades \& Luintel (2001). b) Liquidity variables: Total value traded/GDP ratio (Levine \& Zevros 1996, 1998, Wachtel 2001, Caporale et al. 2005, Brasoveanu et al. 2008, Boubakari et. al 2010, Ndako 2010, Herve \& Shen 2011; Stock market turnover ratio (Levine \& Zevros 1996,1998, Yay \& Oktayer 2009, Boubakari et. al 2010, Ndako 2010, Zivengwa et al. 2011; c) Volatility variables: Arestis, Demetriades and Luintel 2001, Brasoveanu et. al 2008.

\section{Methodology and data}

Our data consists of aggregated observations for the main regions of the world, as presented by the World Bank's World Development Indicators database. Bearing in mind that the majority of the studies were conducted in developed countries or regions, we have chosen to analyze only the developing part of each region. Thus, we were interested to see whether there are any correlations between different 
Borlea S.N., Mare C., Achim M.V., Puscas A. (2016)

Direction of causality between financial development and economic growth. Evidence for developing countries

indicators of the financial market and the economic development for the developing part of each region constructed by the World Bank through its Statistics Bureau. The regions taken in the analysis are: Europe and Central Asia, East Asia and the Pacific, South Asia, the Middle East and North Africa, Sub-Saharan Africa, the Arab world, and Latin America and the Caribbean.

For comparison purposes, we have also included in the sample the North American countries, the Euro Area and the European Union as a whole, because they are the main benchmarks of the financial markets. Following the literature and considering the availability of data, we used the GDP growth rate (RGDP) as a proxy for the economic development and three financial market indicators: market capitalization as a share of GDP (MK_GDP), stocks traded as a share of GDP (ST_GDP) and stocks- traded turnover ratio (ST_TR).

Annual data in the period 1988-2011 (24 years) were considered for this analysis.

To assess the relationships, we have employed time- series analysis methods. Because we were interested to see interconnections between the variables, after analyzing the properties of the data (e.g., descriptive, and unit root, etc), the first factor considered was the correlation coefficient. This coefficient shows the strength and the direction of the relationship between two variables.

In times- series analysis, co-movements of the variables, which were assessed using the cross-correlations, are of major importance. For two time series $x_{t}$ and $y_{t}$, the correlation between $x_{t}$ and $y_{t+k}$ is the cross-correlation for the $k$ lag between the series. The correlograms and cross-correlograms of the variables were computed. The cross-correlations between two time series $x_{t}$ and $y_{t}$ are given by

$$
r_{x y}(l)=\frac{c_{x y}(l)}{\sqrt{c_{x x}(0)} \times \sqrt{c_{y y}(0)}}
$$

where "l" gives the rank of the lag / lead and

$$
c_{x y}(l)=\left\{\begin{array}{l}
\sum_{t=1}^{T-1} \frac{\left[\left(x_{t}-\bar{x}\right) \times\left(y_{t+1}-\bar{y}\right)\right]}{T} \\
\sum_{t=1}^{T+1} \frac{\left[\left(y_{t}-\bar{y}\right) \times\left(x_{t-1}-\bar{x}\right)\right]}{T}
\end{array}\right.
$$

Cross-correlations are not necessarily symmetric around lag 0 .

The values of cross-correlations at different lags indicate the type of relationship between two variables. A large positive cross-correlation coefficient at lag/lead 0

8 DE GRUYTER OPEN
Studia Universitatis "Vasile Goldis" Arad. Economics Series Vol 26 Issue 2/2016

ISSN: 1584-2339; (online) ISSN: 2285 - 3065.

Web: publicatii.uvvg.ro/index.php/studiaeconomia.Pages 1 - 22 
Borlea S.N., Mare C., Achim M.V., Puscas A. (2016)

Direction of causality between financial development and economic growth. Evidence for developing countries

indicates a direct co-movement between two variables. In other words, they evolve similarly. At the same time, a large negative correlation coefficient at lag/lead 0 is an indicator of an inverse co-movement. In this case, when analyzing two variables, the growth of one, leads to the reduction of the other. The crosscorrelation coefficient at lag 0 is, in fact, the correlation coefficient in the correlation matrix.

Moreover, if when the maximum cross-correlation coefficient is at a lag/lead different from 0 , it means that one variable is lagged or leaded by the other in a certain period; i.e., changes in that variable are either determined by changes in the other, either or lead to changes in the other.

The last aspect of the analysis presented in this paper relates to establishing whether there is any long- term equilibrium relationship between the two variables. Therefore, we have employed the Granger causality analysis. Time- series theory states that, whereas the vector approach emphasizes the existence of a mediumterm equilibrium relationship, the Granger causality is valid over the long term.

The null hypothesis of the test is that $\mathrm{Y}$ is not a Granger cause for $\mathrm{X}$. To accept the null hypothesis, the coefficients of $Y_{\mathrm{t}-\mathrm{j}}$ from the regression must be equal to 0 .

$$
X_{t}=\mu+\sum_{i=1}^{k} \varphi_{i} X_{t-i}+\sum_{j=0}^{k} \delta_{j} Y_{t-j}+\varepsilon_{t}
$$

$\delta_{\mathrm{j}}=0$, for $\mathrm{j} \epsilon[0 ; \mathrm{k}]$, with $\mathrm{k}$ fixed so that the residuals resulted from the equation are noise.

In the other sense, to accept the null, the coefficients of the $\mathrm{X}$ terms must be 0 in the regression model

$$
Y_{t}=\mu+\sum_{i=1}^{k} \beta_{i} Y_{t-i}+\sum_{j=0}^{k} \alpha_{j} X_{t-j}+\varepsilon_{t}
$$

$\alpha_{\mathrm{j}}=0$, for $\mathrm{j} \in[0 ; \mathrm{k}]$, with $\mathrm{k}$ fixed so that the residuals resulting from the equation are noises.

In both cases, accepting or rejecting the null hypothesis is based on a Fisher Snedecor test. If the F statistic is higher than the critical one, the null is rejected. Depending on upon the results, there are the following possibilities: the variables are independent; there is a one-way causality; or there is a two-way causality.

Tables related to the Granger causality analysis show the optimum lag number as emphasized by the co- integration methodology based on a vectorial approach.

\section{Results and discussions}

As presented in the literature review, the field's literature has found different relationships between the financial indicators and level of development depending on the time and space considered. The present study is the result of some 
Borlea S.N., Mare C., Achim M.V., Puscas A. (2016)

Direction of causality between financial development and economic growth. Evidence for developing countries

introductory assessments of the subject, intended to draw a picture of the relevant relationships.

We have analyzed the relationship of the financial market and the development level of a country from three perspectives:

- market capitalization vs. economic development,

- stocks traded as a share of GDP vs. economic development,

- stocks' traded turnover ratio vs. economic development.

\section{Market capitalization vs. Economic development}

The correlation coefficients show that for all regions, there is a direct relationship between the market capitalization level and the level of economic development. Because all correlation coefficients are positive, this means that a higher GDP growth rate, is associated with a higher market capitalization, and vice-versa. However, the relationship is not strong in any of the cases. The results emphasize the existence of a medium- intensity relationship between the two variables in the developing parts of 6 of the 7 regions considered: the Arab world, East Asia and the Pacific, Europe and Central Asia, Latin America and the Caribbean, and South Asia and Sub-Saharan Africa (the coefficients range between 0.3 and 0.7).

In the Middle East and North Africa region, the connection between financial markets and the economic development is weak, with a coefficient of only 0.11 . The same type of results was also found for the analyzed benchmarks. The highest correlation value obtained for these benchmarks was obtained in North America (0.24), followed closely by the European Union (0.23), which, however, shows that the financial market in the period under analysis was not significantly influenced by the level of economic development. The lowest intensity was found for the Euro Area.

Table 2 Correlation coefficients

\begin{tabular}{|l|l|}
\hline Arab world (Arb) & 0.5207 \\
\hline East Asia \& the Pacific (Eap) & 0.4358 \\
\hline Europe and Central Asia (Eca) & 0.5894 \\
\hline Euro Area (Emu) & $\mathbf{0 . 1 0 6 8}$ \\
\hline European Union (Euu) & 0.2288 \\
\hline Latin America \& the Caribbean (Lac) & 0.4318 \\
\hline Middle East \& North Africa (Mna) & 0.1147 \\
\hline North America (Nac) & 0.2409 \\
\hline South Asia (Sas) & 0.6234 \\
\hline Sub-Saharan Africa (Ssa) & $\mathbf{0 . 6 8 2 1}$ \\
\hline
\end{tabular}

Source: own calculations based on World Bank data 
Borlea S.N., Mare C., Achim M.V., Puscas A. (2016)

Direction of causality between financial development and economic growth. Evidence for developing countries

After briefly analyzing the relationship based on the simple correlation coefficients, we were interested to see the timing between the market capitalization and the economic development, expressed by the GDP growth rate. Tables 3 and 4 present the results of the cross-correlation analyses.

There are four regions in which the market capitalization and growth rate of the GDP are related - East Asia and the Pacific, Latin America and the Caribbean, and South Asia and Sub-Saharan Africa. In the developing countries of these regions, at an aggregated level, changes in the GDP are immediately felt on the financial market, measured through the market capitalization indicator.

Economic development leads the financial markets in other analyzed regions. Thus, in the Arab regions, changes in the GDP growth rate will be felt in the next year in the share of the market capitalization in the GDP with quite a high intensity (67.2 $\%$ ). With a same intensity, the financial markets will react to changes in economic development in Europe and Central Asia (coefficient of 0.63). But this time, the reaction will occur slightly later, that is, after 2 years. Thus, the GDP growth rate in this region leads the market capitalization by two periods. In the Middle East and North Africa, the reaction of the financial markets to changes in the economic development of the region is slower. An innovation in the GDP growth rate will be felt in the market capitalization after 5 years, although with a medium intensity. In both groups described above, the economic development and financial markets are positively correlated.

Table 3 Cross - correlations - part 1

\begin{tabular}{|c|c|c|c|c|c|c|c|c|c|c|}
\hline \multirow{2}{*}{ I } & \multicolumn{2}{|c|}{ Arab world (Arb) } & \multicolumn{2}{c|}{$\begin{array}{c}\text { East Asia \& the } \\
\text { Pacific (Eap) }\end{array}$} & \multicolumn{2}{c|}{$\begin{array}{c}\text { Europe and } \\
\text { Central Asia (Eca) }\end{array}$} & \multicolumn{2}{c|}{ Euro Area (Emu) } & \multicolumn{2}{|c|}{$\begin{array}{c}\text { European Union } \\
\text { (Euu) }\end{array}$} \\
\cline { 2 - 12 } & lag & Lead & Lag & Lead & \multicolumn{1}{l|}{ lag } & \multicolumn{1}{l|}{ lead } & \multicolumn{1}{c|}{ Lag } & \multicolumn{1}{l|}{ lead } & \multicolumn{1}{l|}{ lag } & lead \\
\hline 0 & 0.5207 & 0.5207 & $\mathbf{0 . 4 3 5 8}$ & $\mathbf{0 . 4 3 5 8}$ & 0.5894 & 0.5894 & 0.1068 & 0.1068 & 0.2288 & 0.2288 \\
\hline 1 & $\mathbf{0 . 6 7 2 0}$ & 0.5667 & 0.2633 & 0.1409 & 0.5188 & 0.5446 & -0.0123 & 0.0939 & 0.0863 & $\mathbf{0 . 2 6 2 8}$ \\
\hline 2 & 0.2918 & 0.1308 & 0.2115 & -0.1570 & $\mathbf{0 . 6 2 6 6}$ & 0.0357 & -0.1139 & $\mathbf{- 0 . 3 2 8 6}$ & -0.0044 & -0.2350 \\
\hline 3 & -0.0420 & 0.0352 & 0.1943 & 0.0334 & 0.5809 & 0.0895 & -0.1160 & -0.3070 & 0.0046 & -0.2586 \\
\hline 4 & -0.2269 & -0.2840 & 0.0938 & 0.0515 & 0.4833 & -0.0653 & -0.1799 & -0.1959 & -0.0630 & -0.1850 \\
\hline 5 & -0.2239 & -0.3749 & -0.1144 & -0.0114 & 0.2999 & -0.0895 & -0.1334 & -0.1334 & -0.0256 & -0.1504 \\
\hline 6 & -0.2937 & -0.3616 & -0.1618 & 0.1430 & 0.3136 & -0.1659 & -0.0977 & -0.1062 & -0.0334 & -0.1303 \\
\hline 7 & -0.0133 & -0.2230 & -0.1587 & 0.2022 & 0.2672 & -0.1203 & -0.0883 & -0.0493 & -0.0844 & -0.0642 \\
\hline 8 & -0.1982 & -0.0952 & -0.4743 & 0.0058 & 0.0520 & -0.2073 & -0.0316 & -0.2136 & -0.0949 & -0.2549 \\
\hline
\end{tabular}

Source: own calculations based on World Bank data.

The last group encompasses regions in which the financial markets lead the economic development level, showing a high sensitivity for the former. These are the three developed regions taken into analysis for comparison purposes. In the Euro Area, any change in the level of the market capitalization will determine a variation in the GDP growth rate after 2 years, but negatively. In addition, a negative correlation was found on the North American financial markets. However, 
Borlea S.N., Mare C., Achim M.V., Puscas A. (2016)

Direction of causality between financial development and economic growth. Evidence for developing countries

for these markets, changes in the share of market capitalization in the GDP will be felt in the evolution of the GDP growth rate only after 4 years, which is quite a long period. For the European Union, we have found a positive cross-correlation coefficient at lead 1. Combining these results with the ones of the Euro Area, we can conclude that the correlation between financial markets and economic development is positive and higher in the non-Euro Area member states of the Union.

Table 4 Cross - correlations - part 2

\begin{tabular}{|c|c|c|c|c|c|c|c|c|c|c|}
\hline \multirow{2}{*}{ I } & $\begin{array}{c}\text { Latin America \& } \\
\text { the Caribbean } \\
\text { (Lac) }\end{array}$ & \multicolumn{2}{c|}{$\begin{array}{c}\text { Middle East \& } \\
\text { North Africa (Mna) }\end{array}$} & \multicolumn{2}{c|}{$\begin{array}{c}\text { North America } \\
\text { (Nac) }\end{array}$} & \multicolumn{2}{|c|}{ South Asia (Sas) } & \multicolumn{2}{c|}{$\begin{array}{c}\text { Sub-Saharan } \\
\text { Africa (Ssa) }\end{array}$} \\
\cline { 2 - 12 } & lag & Lead & Lag & Lead & lag & lead & Lag & lead & lag & lead \\
\hline 0 & $\mathbf{0 . 4 3 1 8}$ & $\mathbf{0 . 4 3 1 8}$ & 0.1147 & 0.1147 & 0.2409 & 0.2409 & $\mathbf{0 . 6 2 3 4}$ & $\mathbf{0 . 6 2 3 4}$ & $\mathbf{0 . 6 8 2 1}$ & $\mathbf{0 . 6 8 2 1}$ \\
\hline 1 & 0.2197 & 0.3537 & 0.3490 & -0.0608 & 0.2168 & 0.2106 & 0.4503 & 0.3278 & -0.0011 & 0.5680 \\
\hline 2 & 0.3705 & -0.2160 & 0.2048 & -0.0355 & 0.1579 & -0.2188 & 0.3175 & 0.3702 & 0.0873 & 0.2617 \\
\hline 3 & 0.3531 & 0.0516 & 0.3166 & -0.4082 & 0.1503 & -0.2792 & 0.3298 & 0.3304 & 0.1768 & -0.2719 \\
\hline 4 & 0.0102 & 0.0234 & 0.0239 & -0.1579 & 0.0906 & $-\mathbf{0 . 3 9 5 1}$ & 0.2345 & 0.1083 & 0.2450 & -0.3604 \\
\hline 5 & -0.0696 & -0.0037 & $\mathbf{0 . 4 9 9 1}$ & 0.0846 & 0.1019 & -0.3410 & -0.0280 & 0.0244 & 0.1701 & -0.2640 \\
\hline 6 & -0.0368 & -0.0102 & -0.1554 & -0.0150 & 0.0917 & -0.2879 & -0.0391 & -0.0205 & 0.2102 & -0.1472 \\
\hline 7 & -0.0769 & 0.0641 & 0.0729 & 0.0371 & 0.1446 & -0.2038 & -0.1084 & -0.0417 & -0.0235 & -0.0834 \\
\hline 8 & -0.2350 & -0.1153 & -0.2930 & 0.0815 & -0.0125 & -0.4105 & -0.1181 & -0.0436 & 0.2275 & -0.0243 \\
\hline
\end{tabular}

Source: own calculations based on World Bank data.

Table 5 Granger causality

\begin{tabular}{|c|c|c|c|}
\hline Region & Lag & $\begin{array}{c}\text { Hypothesis } \\
\end{array}$ & Prob. \\
\hline \multirow{2}{*}{ Arab world (Arb) } & \multirow{2}{*}{2} & RGDP does not Granger Cause MK & 0.3038 \\
\hline & & MK does not Granger Cause RGDP & 0.0230 \\
\hline \multirow{2}{*}{ East Asia \& the Pacific (Eap) } & \multirow{2}{*}{1} & RGDP does not Granger Cause MK & 0.6287 \\
\hline & & MK does not Granger Cause RGDP & 0.6168 \\
\hline \multirow{2}{*}{ Europe And Central Asia (Eca) } & \multirow{2}{*}{2} & RGDP does not Granger Cause MK & 0.2262 \\
\hline & & MK does not Granger Cause RGDP & 0.0032 \\
\hline \multirow{2}{*}{ Euro Area (Emu) } & \multirow{2}{*}{2} & RGDP does not Granger Cause MK & 0.4453 \\
\hline & & MK does not Granger Cause RGDP & 0.0001 \\
\hline \multirow{2}{*}{ European Union (Euu) } & \multirow{2}{*}{2} & RGDP does not Granger Cause MK & 0.6105 \\
\hline & & MK does not Granger Cause RGDP & 0.0000 \\
\hline \multirow{2}{*}{ Latin America \& the Caribbean (Lac) } & \multirow{2}{*}{2} & RGDP does not Granger Cause MK & 0.8900 \\
\hline & & MK does not Granger Cause RGDP & 0.0076 \\
\hline \multirow{2}{*}{ Middle East \& North Africa (Mna) } & \multirow{2}{*}{2} & RGDP does not Granger Cause MK & 0.6287 \\
\hline & & MK does not Granger Cause RGDP & 0.8614 \\
\hline \multirow{2}{*}{ North America (Nac) } & \multirow{2}{*}{2} & RGDP does not Granger Cause MK & 0.6342 \\
\hline & & MK does not Granger Cause RGDP & 0.0001 \\
\hline \multirow{2}{*}{ South Asia (Sas) } & \multirow{2}{*}{1} & RGDP does not Granger Cause MK & 0.5388 \\
\hline & & MK does not Granger Cause RGDP & 0.3310 \\
\hline \multirow{2}{*}{ Sub-Saharan Africa (Ssa) } & \multirow[b]{2}{*}{1} & RGDP does not Granger Cause MK & 0.4712 \\
\hline & & MK does not Granger Cause RGDP & 0.1673 \\
\hline
\end{tabular}

Source: own calculations based on World Bank data. 
Borlea S.N., Mare C., Achim M.V., Puscas A. (2016)

Direction of causality between financial development and economic growth. Evidence for developing countries

The last aspect presented in this study relates to the assessment of the long- term equilibrium relationship between the economic development and financial markets. In a few cases, such a relationship was validated but only as a one-way causality, never as bilateral causality. Over the long term, it is the market capitalization that Granger causes the GDP growth rate in the following regions: the Arab World, Europe and Central Asia, Euro Area, European Union, Latin America and the Caribbean and North America.

Stocks traded as a share of GDP vs. Economic development

Concerning the share of the stocks traded in the GDP and the level of the economic development, there are both negative and positive correlations. The highest levels of correlation are to be found in the Sub-Saharan Africa and the Arab world (values above 0.6). Additionally, medium intensity correlations were found for the developing countries from Latin America and Europe and Central Asia, followed in intensity by the those from North America and South Asia. However, the financial markets measured through the stocks traded as a share of the GDP is negatively correlated with the GDP growth rate in North American economies. Thus, an increase in the latter indicator would lead to a reduction in the first. We can conclude that there is no correlation between the economic development of the region and the financial markets measured through stocks traded (as a share of the GDP) in the Euro Area, the European Union and the Middle East and North Africa.

Table 6 Correlation coefficients

\begin{tabular}{|l|c|}
\hline Arab world (Arb) & 0.6071 \\
\hline East Asia \& the Pacific (Eap) & 0.2267 \\
\hline Europe and Central Asia (Eca) & 0.4225 \\
\hline Euro Area (Emu) & $\mathbf{0 . 0 0 3 7}$ \\
\hline European Union (Euu) & 0.0469 \\
\hline Latin America \& the Caribbean (Lac) & 0.4317 \\
\hline Middle East \& North Africa (Mna) & -0.0982 \\
\hline North America (Nac) & -0.3336 \\
\hline South Asia (Sas) & 0.3134 \\
\hline Sub-Saharan Africa (Ssa) & $\mathbf{0 . 6 1 6 6}$ \\
\hline
\end{tabular}

Source: own calculations based on World Bank data.

Only in the Sub-Saharan African countries are the GDP growth rate and share of the stocks traded in the GDP correlated, with a coefficient of 0.62. In the rest of other regions, the economic development level either leads or is leaded by financial markets, based on the two indicators analyzed. 
Borlea S.N., Mare C., Achim M.V., Puscas A. (2016)

Direction of causality between financial development and economic growth. Evidence for developing countries

\begin{tabular}{|c|c|c|c|c|c|c|c|c|c|c|}
\hline \multicolumn{11}{|c|}{ Table 7 Cross - correlations - part 1} \\
\hline \multirow[t]{2}{*}{ i } & \multicolumn{2}{|c|}{ Arab world (Arb) } & \multicolumn{2}{|c|}{$\begin{array}{l}\text { East Asia \& the } \\
\text { Pacific (Eap) }\end{array}$} & \multicolumn{2}{|c|}{$\begin{array}{c}\text { Europe and } \\
\text { Central Asia (Eca) }\end{array}$} & \multicolumn{2}{|c|}{ Euro Area (Emu) } & \multicolumn{2}{|c|}{$\begin{array}{c}\text { European Union } \\
\text { (Euu) }\end{array}$} \\
\hline & Lag & lead & lag & lead & Lag & lead & lag & lead & lag & lead \\
\hline 0 & 0.6071 & 0.6071 & 0.2267 & 0.2267 & 0.4225 & 0.4225 & 0.0037 & 0.0037 & 0.0469 & 0.0469 \\
\hline 1 & 0.6701 & 0.4303 & 0.2180 & -0.0745 & 0.2210 & 0.1189 & 0.1047 & -0.2971 & 0.1562 & -0.2717 \\
\hline 2 & 0.4534 & 0.2373 & 0.2874 & -0.1276 & 0.4656 & -0.1367 & -0.0437 & -0.4775 & 0.0466 & -0.4830 \\
\hline 3 & 0.0026 & -0.0988 & 0.3287 & 0.1037 & 0.5516 & -0.1202 & -0.1367 & -0.3103 & -0.0029 & -0.2603 \\
\hline 4 & -0.3582 & -0.3290 & 0.2457 & 0.0484 & 0.4608 & -0.0098 & -0.1873 & -0.1641 & -0.0516 & -0.2079 \\
\hline 5 & -0.2951 & -0.3409 & 0.0590 & 0.0546 & 0.3039 & -0.1318 & -0.1723 & -0.0640 & -0.0576 & -0.1502 \\
\hline 6 & -0.2764 & -0 . & -0.1107 & 0.1811 & 0.1472 & -0.1809 & -0.0560 & -0.0897 & 0.0232 & -0.1329 \\
\hline 7 & -0.1946 & -0.2008 & -0.1334 & 0.2083 & 0.2648 & -0.1037 & 0.0163 & -0.1772 & 0.0894 & -0.1941 \\
\hline 8 & -0.0423 & -0.0875 & -0.3704 & 0.0337 & 0.0448 & -0.2461 & 0.0119 & -0.2607 & 0.0599 & -0.2698 \\
\hline
\end{tabular}

Source: own calculations based on World Bank data.

Table 8 Cross - correlations - part 2

\begin{tabular}{|c|c|c|c|c|c|c|c|c|c|c|}
\hline \multirow{2}{*}{ i } & \multicolumn{2}{|c|}{$\begin{array}{c}\text { Latin America \& } \\
\text { the Caribbean } \\
\text { (Lac) }\end{array}$} & \multicolumn{2}{c|}{$\begin{array}{c}\text { Middle East \& } \\
\text { North Africa (Mna) }\end{array}$} & \multicolumn{2}{c|}{$\begin{array}{c}\text { North America } \\
\text { (Nac) }\end{array}$} & \multicolumn{2}{c|}{ South Asia (Sas) } & \multicolumn{2}{c|}{$\begin{array}{c}\text { Sub-Saharan } \\
\text { Africa (Ssa) }\end{array}$} \\
\cline { 2 - 13 } & $\mathbf{L a g}$ & lead & Lag & lead & Lag & lead & lag & lead & \multicolumn{1}{c|}{ lag } & lead \\
\hline 0 & 0.4317 & 0.4317 & -0.0982 & -0.0982 & -0.3336 & -0.3336 & 0.3134 & 0.3134 & $\mathbf{0 . 6 1 6 6}$ & $\mathbf{0 . 6 1 6 6}$ \\
\hline 1 & 0.3386 & -0.0130 & 0.3700 & -0.1510 & -0.0639 & -0.3274 & 0.4076 & 0.3080 & 0.2785 & 0.5255 \\
\hline 2 & 0.4913 & -0.1525 & $\mathbf{0 . 5 0 2 0}$ & -0.1864 & 0.1601 & -0.3517 & 0.3366 & 0.3087 & 0.3566 & 0.4962 \\
\hline 3 & $\mathbf{0 . 5 0 5 0}$ & -0.0259 & 0.3497 & -0.2744 & 0.2054 & -0.2362 & 0.2236 & $\mathbf{0 . 4 1 9 3}$ & 0.1874 & 0.2885 \\
\hline 4 & 0.2422 & -0.1643 & 0.1545 & -0.1072 & 0.1451 & -0.2124 & 0.2365 & 0.3340 & 0.0408 & 0.4343 \\
\hline 5 & -0.0241 & -0.1960 & 0.4767 & -0.0643 & 0.0683 & -0.2218 & 0.0507 & 0.3457 & -0.0578 & 0.2594 \\
\hline 6 & -0.1388 & -0.0552 & -0.1491 & -0.0948 & 0.0415 & -0.2737 & -0.1789 & 0.3395 & -0.0699 & 0.1358 \\
\hline 7 & -0.2357 & 0.0133 & -0.1294 & -0.0234 & 0.0758 & -0.4145 & -0.2995 & 0.3044 & -0.2636 & -0.0098 \\
\hline 8 & -0.2923 & -0.0597 & -0.2854 & -0.1116 & 0.1009 & $-\mathbf{0 . 4 8 5 2}$ & -0.2688 & 0.0895 & -0.2415 & -0.1637 \\
\hline
\end{tabular}

Source: own calculations based on World Bank data.

The GDP growth rate leads the share of stocks traded with different lags (meaning a delay of $n$ years) in countries of the following regions:

- The Arab world - coefficient 0.67, lag 1;

- Europe and Central Asia - coefficient 0.55, lag 3;

- Latin America and the Caribbean - coefficient 0.505, lag 3;

- Middle East and North Africa - coefficient 0.502, lag 2;

- East Asia and the Pacific - coefficient 0.33, lag 3.

For all these countries, any change in the growth rate of the GDP will determine an increase in the share of the stocks traded in the GDP after maximum 3 years.

In South Asia, the GDPGDP growth rate is influenced by the evolution of financial markets. However, reactions of the economic development level to changes in the financial markets will manifest at their highest intensity after 3 years.

The results for the most developed financial markets are the same. In the Euro Area, the European Union and North America, the economic development lags the financial one. Moreover, in the first and last case, even the direction of the relationship is the same - negative. Thus, the negative influence is also emphasized 
Borlea S.N., Mare C., Achim M.V., Puscas A. (2016)

Direction of causality between financial development and economic growth. Evidence for developing countries

by the analysis for the European Union as a whole, too. The influence will be felt at its highest intensity after 2 years in the countries of the European Union and the Euro Area, whereas for the North American countries, the lag is quite high -8 years.

Long- term equilibrium is even poorer in the case of stocks traded than in the case of market capitalization, both as a share of the GDP. The analysis reveals two causal relationships at the $5 \%$ level and two at the $10 \%$ level.

Table 9 Granger causality

\begin{tabular}{|c|c|c|c|}
\hline Region & Lag & Hypothesis & Prob. \\
\hline \multirow{2}{*}{ Arab world (Arb) } & \multirow{2}{*}{2} & RGDP does not Granger Cause ST_GDP & 0.2630 \\
\hline & & ST_GDP does not Granger Cause RGDP & 0.3015 \\
\hline \multirow{2}{*}{$\begin{array}{l}\text { East Asia \& the Pacific } \\
\text { (Eap) }\end{array}$} & \multirow{2}{*}{1} & RGDP does not Granger Cause ST_GDP & 0.6169 \\
\hline & & ST_GDP does not Granger Cause RGDP & 0.3377 \\
\hline \multirow{2}{*}{$\begin{array}{l}\text { Europe and Central } \\
\text { Asia (Eca) }\end{array}$} & \multirow{2}{*}{1} & RGDP does not Granger Cause ST_GDP & 0.7282 \\
\hline & & ST_GDP does not Granger Cause RGDP & 0.7684 \\
\hline \multirow{2}{*}{ Euro Area (Emu) } & \multirow{2}{*}{2} & RGDP does not Granger Cause ST_GDP & 0.1765 \\
\hline & & ST_GDP does not Granger Cause RGDP & $\mathbf{0 . 0 3 2 2}$ \\
\hline \multirow{2}{*}{ European Union (Euu) } & \multirow{2}{*}{2} & RGDP does not Granger Cause ST_GDP & 0.2372 \\
\hline & & ST_GDP does not Granger Cause RGDP & $0.0600 *$ \\
\hline \multirow{2}{*}{$\begin{array}{l}\text { Latin America \& the } \\
\text { Caribbean (Lac) }\end{array}$} & \multirow{2}{*}{1} & RGDP does not Granger Cause ST_GDP & 0.5618 \\
\hline & & ST_GDP does not Granger Cause RGDP & 0.8390 \\
\hline \multirow{2}{*}{$\begin{array}{l}\text { Middle East \& North } \\
\text { Africa (Mna) }\end{array}$} & \multirow{2}{*}{0} & RGDP does not Granger Cause ST_GDP & 0.6191 \\
\hline & & ST_GDP does not Granger Cause RGDP & 0.5336 \\
\hline \multirow{2}{*}{ North America (Nac) } & \multirow{2}{*}{1} & RGDP does not Granger Cause ST_GDP & 0.0808* \\
\hline & & ST_GDP does not Granger Cause RGDP & 0.4661 \\
\hline \multirow{2}{*}{ South Asia (Sas) } & \multirow{2}{*}{1} & RGDP does not Granger Cause ST_GDP & 0.1119 \\
\hline & & ST_GDP does not Granger Cause RGDP & 0.2731 \\
\hline \multirow{2}{*}{$\begin{array}{l}\text { Sub-Saharan Africa } \\
\text { (Ssa) }\end{array}$} & \multirow{2}{*}{2} & RGDP does not Granger Cause ST_GDP & 0.0487 \\
\hline & & ST_GDP does not Granger Cause RGDP & 0.2537 \\
\hline
\end{tabular}

*significant at the $10 \%$ level.

Source: own calculations based on World Bank data.

Firstly, the share of the stocks traded in the GDP is a Granger cause on over the long term for the GDP growth rate in the Euro Area. This shows that the financial markets of the Euro Area are more sensitive to any change and their reactions will be transmitted further in the economic development of the EMU. Additionally, a one-way causality, from the GDP growth rate toward financial markets, is validated for the Sub-Saharan economies. Secondly, at a $10 \%$ significance level, the financial market is a Granger cause for the economic markets in the European Union, whereas in the North American economies, the relationship is reversed, and the growth rate of the GDP causes changes in the share of the stocks traded. 
Borlea S.N., Mare C., Achim M.V., Puscas A. (2016)

Direction of causality between financial development and economic growth. Evidence for developing countries

\section{Stocks- traded turnover ratio vs. Economic development}

The Sub-Saharan economies prove, once again, to have the highest correlation between the financial and economic markets. The relationship is positive, just as in the case of the Arab countries or the Latin American countries. In all these cases, a high level of the GDP growth rate is accompanied by a high turnover rate of stocks traded on the financial market.

For the developing countries of the Middle East and North Africa, the correlation coefficient reveals a low intensity of the relationship.

A high, but negative correlation is found in the case of North American states, 0.56 , between the growth rate of the GDP and the turnover ratio of the stocks traded. In other words, in countries such as Canada and the USA, a low GDP growth rate will be accompanied by a high turnover frequency for the financial market investors.

Table 10 Correlation coefficients

\begin{tabular}{|l|c|}
\hline Arab world (Arb) & 0.4425 \\
\hline East Asia \& the Pacific (Eap) & 0.1462 \\
\hline Europe and Central Asia (Eca) & $\mathbf{0 . 0 3 1 0}$ \\
\hline Euro Area (Emu) & -0.0676 \\
\hline European Union (Euu) & -0.0916 \\
\hline Latin America \& the Caribbean (Lac) & 0.3315 \\
\hline Middle East \& North Africa (Mna) & 0.2162 \\
\hline North America (Nac) & -0.5581 \\
\hline South Asia (Sas) & -0.0735 \\
\hline Sub-Saharan Africa (Ssa) & $\mathbf{0 . 6 2 3 4}$ \\
\hline
\end{tabular}

Source: own calculations based on World Bank data.

Table 11 Cross - correlations - part 1

\begin{tabular}{|c|c|c|c|c|c|c|c|c|c|c|}
\hline \multirow{2}{*}{$\mathbf{i}$} & \multicolumn{2}{|c|}{ Arab world (Arb) } & \multicolumn{2}{c|}{$\begin{array}{c}\text { East Asia \& the } \\
\text { Pacific (Eap) }\end{array}$} & \multicolumn{2}{c|}{$\begin{array}{c}\text { Europe and Central } \\
\text { Asia (Eca) }\end{array}$} & \multicolumn{2}{c|}{ Euro Area (Emu) } & \multicolumn{2}{c|}{$\begin{array}{c}\text { European Union } \\
\text { (Euu) }\end{array}$} \\
\cline { 2 - 12 } & $\mathbf{L a g}$ & $\mathbf{L e a d}$ & $\mathbf{l a g}$ & lead & Lag & lead & lag & lead & \multicolumn{1}{l|}{ lag } & lead \\
\hline $\mathbf{0}$ & $\mathbf{0 . 4 4 2 5}$ & $\mathbf{0 . 4 4 2 5}$ & 0.1462 & 0.1462 & 0.0310 & 0.0310 & -0.0676 & -0.0676 & -0.0916 & -0.0916 \\
\hline $\mathbf{1}$ & 0.3978 & 0.3157 & 0.1309 & -0.0934 & $\mathbf{- 0 . 4 4 8 0}$ & 0.1068 & 0.1056 & -0.3519 & 0.1267 & -0.3871 \\
\hline $\mathbf{2}$ & 0.1906 & 0.2581 & 0.2601 & -0.2226 & -0.2772 & 0.2570 & -0.0255 & $\mathbf{- 0 . 3 5 4 9}$ & 0.0853 & $\mathbf{- 0 . 4 1 7 2}$ \\
\hline $\mathbf{3}$ & -0.0003 & 0.1292 & 0.3714 & -0.0367 & -0.2612 & 0.0935 & -0.1128 & -0.2433 & 0.0532 & -0.2345 \\
\hline $\mathbf{4}$ & -0.2061 & -0.0509 & $\mathbf{0 . 3 8 5 3}$ & -0.1337 & -0.0918 & 0.2016 & -0.1133 & -0.1966 & 0.0327 & -0.2688 \\
\hline $\mathbf{5}$ & -0.1488 & -0.0981 & 0.2781 & -0.1417 & 0.0326 & 0.1588 & -0.0746 & -0.1834 & 0.0213 & -0.2806 \\
\hline $\mathbf{6}$ & -0.1528 & -0.0643 & 0.0735 & 0.0837 & -0.0303 & 0.0077 & 0.0483 & -0.2142 & 0.0897 & -0.2294 \\
\hline $\mathbf{7}$ & -0.1437 & 0.0261 & -0.0504 & 0.2655 & 0.0127 & 0.1557 & 0.1757 & -0.2900 & 0.2108 & -0.2505 \\
\hline $\mathbf{8}$ & -0.1429 & 0.0606 & -0.2686 & 0.2313 & -0.1377 & 0.0668 & 0.1528 & -0.1991 & 0.2242 & -0.1935 \\
\hline
\end{tabular}

Source: own calculations based on World Bank data.

The Arab and the North American economies are the only ones in which the GDP growth rate and turnover ratio of the stocks traded are correlated. In the former, just 
Borlea S.N., Mare C., Achim M.V., Puscas A. (2016)

Direction of causality between financial development and economic growth. Evidence for developing countries

as presented in table 6 , the relationship is positive, whereas in the latter, the relationship is negative.

Table 12 Cross - correlations - part 2

\begin{tabular}{|c|c|c|c|c|c|c|c|c|c|c|}
\hline \multirow{2}{*}{$\mathbf{i}$} & $\begin{array}{c}\text { Latin America \& } \\
\text { the Caribbean } \\
\text { (Lac) }\end{array}$ & \multicolumn{2}{c|}{$\begin{array}{c}\text { Middle East \& } \\
\text { North Africa (Mna) }\end{array}$} & \multicolumn{2}{|c|}{$\begin{array}{c}\text { North America } \\
\text { (Nac) }\end{array}$} & \multicolumn{2}{|c|}{ South Asia (Sas) } & \multicolumn{2}{c|}{$\begin{array}{c}\text { Sub-Saharan } \\
\text { Africa (Ssa) }\end{array}$} \\
\cline { 2 - 12 } & $\mathbf{L a g}$ & Lead & lag & lead & Lag & lead & lag & lead & lag & lead \\
\hline $\mathbf{0}$ & 0.3315 & 0.3315 & 0.2162 & 0.2162 & $\mathbf{- 0 . 5 5 8 1}$ & $\mathbf{- 0 . 5 5 8 1}$ & -0.0735 & -0.0735 & 0.6234 & 0.6234 \\
\hline $\mathbf{1}$ & 0.2758 & -0.1645 & $\mathbf{0 . 3 8 7 6}$ & 0.0915 & -0.2218 & -0.3367 & 0.0096 & -0.0283 & 0.6817 & 0.6125 \\
\hline $\mathbf{2}$ & 0.2893 & -0.2184 & 0.3093 & 0.1243 & 0.0979 & -0.2970 & 0.0385 & 0.0522 & $\mathbf{0 . 7 2 0 4}$ & 0.5675 \\
\hline $\mathbf{3}$ & 0.3836 & -0.1329 & 0.0595 & 0.0370 & 0.1960 & -0.2444 & -0.0558 & 0.2550 & 0.6352 & 0.4849 \\
\hline $\mathbf{4}$ & 0.2085 & -0.3941 & 0.1364 & 0.0860 & 0.1725 & -0.1462 & 0.1172 & 0.4264 & 0.4846 & 0.3270 \\
\hline $\mathbf{5}$ & 0.0492 & $\mathbf{- 0 . 4 1 0 1}$ & -0.0465 & -0.0951 & 0.1029 & -0.1985 & 0.0736 & 0.4935 & 0.3119 & 0.1775 \\
\hline $\mathbf{6}$ & -0.0559 & -0.1358 & -0.2234 & -0.0532 & 0.0408 & -0.2515 & -0.0492 & $\mathbf{0 . 5 4 8 1}$ & 0.1437 & 0.0813 \\
\hline $\mathbf{7}$ & -0.2791 & -0.0038 & -0.0916 & -0.0329 & 0.0392 & -0.4220 & -0.1555 & 0.5389 & -0.0025 & 0.0018 \\
\hline $\mathbf{8}$ & -0.2934 & -0.0047 & 0.0050 & -0.0159 & 0.0966 & -0.3634 & -0.1797 & 0.2546 & -0.1073 & -0.0257 \\
\hline
\end{tabular}

Source: own calculations based on World Bank data.

In terms of stocks traded, even from the point of view of turnover ratio, the timing and the sense of the relationship between the financial and the economic markets remain the same for the Euro Area and the European Union. The cross-correlation coefficients are both negative, with the highest value at lead 2 , showing that the turnover ratio of the stocks traded leads the growth rate of the GDP by two years. In Latin America, the intensity and the direction of the relationship are almost the same, with the difference that the economic sector reacts, with the highest intensity, after 5 years, to changes in the financial sector. The countries of South Asia are characterized by the influence of the financial market upon the economic one, with a lead of 6 years. However, in this case, the relationship is positive; an increase in the turnover ratio of the stocks traded will lead to an increase in the GDP growth rate.

Increases in the GDP growth rate will lead to changes in the stocks traded turnover ratio in the case of four regions. In East Asia and Pacific, the influence of the economic sector upon the financial one will be felt at its peak 4 years after the change. In Europe and Central Asia, the same influence will be felt in the next year, but a high GDP growth rate will cause a diminishment of the turnover ratio. Additionally, with a lag of 1 year, the financial markets of the Middle East and North African countries react to changes in their economic markets with a 1-year lag, but the relationship is positive. The most intense reaction was revealed for the Sub-Saharan countries. The growth rate of the GDP leads the stocks traded turnover ratio in this region with an advance of two years. Any increase in the GDP growth, will be followed by an increase in the stocks traded turnover ratio, reaching a correlation coefficient of 0.72 . 
Borlea S.N., Mare C., Achim M.V., Puscas A. (2016)

Direction of causality between financial development and economic growth. Evidence for developing countries

In comparison with the other two types of financial market parameters, in this case, we also found two-way causality relationships between the financial market and the economic one. In the Sub-Saharan economies and the European Union member states, the GDP growth rate is a Granger cause for the turnover ratio of the stock market and vice-versa. In other words, over time, there is a bilateral equilibrium between the two indicators. The GDP growth rate causes changes in the stocks traded turnover ratio in two regions: Europe and Central Asia and North America. There is no one-way causality relationship found from the financial market toward the economic one.

The analysis shows that based on the correlation issues, the strongest connections between the financial markets and the economic development level are to be found in the developing countries of the Sub-Saharan Africa, whereas the least strong, one could even say no inexistent, connections are found in the member states of the European Union and the Euro Area.

Table 13 Granger causality

\begin{tabular}{|c|c|c|c|}
\hline Region & Lag & Hypothesis & Prob. \\
\hline \multirow{2}{*}{ Arab world (Arb) } & \multirow{2}{*}{1} & RGDP does not Granger Cause ST_TR & 0.8323 \\
\hline & & ST_TR does not Granger Cause RGDP & 0.1718 \\
\hline \multirow{2}{*}{$\begin{array}{l}\text { East Asia \& the Pacific } \\
\text { (Eap) }\end{array}$} & \multirow{2}{*}{1} & RGDP does not Granger Cause ST_TR & 0.7037 \\
\hline & & ST_TR does not Granger Cause RGDP & 0.3869 \\
\hline \multirow{2}{*}{$\begin{array}{l}\text { Europe and Central Asia } \\
\text { (Eca) }\end{array}$} & \multirow{2}{*}{1} & RGDP does not Granger Cause ST_TR & 0.0421 \\
\hline & & ST_TR does not Granger Cause RGDP & 0.6214 \\
\hline \multirow{2}{*}{ Euro Area (Emu) } & \multirow{2}{*}{1} & RGDP does not Granger Cause ST_TR & 0.1828 \\
\hline & & ST_TR does not Granger Cause RGDP & 0.1159 \\
\hline \multirow{2}{*}{ European Union (Euu) } & \multirow{2}{*}{1} & RGDP does not Granger Cause ST_TR & 0.0643* \\
\hline & & ST_TR does not Granger Cause RGDP & 0.0924* \\
\hline \multirow{2}{*}{$\begin{array}{l}\text { Latin America \& the } \\
\text { Caribbean (Lac) }\end{array}$} & \multirow{2}{*}{1} & RGDP does not Granger Cause ST_TR & 0.2006 \\
\hline & & ST_TR does not Granger Cause RGDP & 0.6389 \\
\hline \multirow{2}{*}{$\begin{array}{l}\text { Middle East \& North } \\
\text { Africa (Mna) }\end{array}$} & \multirow{2}{*}{1} & RGDP does not Granger Cause ST_TR & 0.2006 \\
\hline & & ST_TR does not Granger Cause RGDP & 0.6389 \\
\hline \multirow{2}{*}{ North America (Nac) } & \multirow{2}{*}{1} & RGDP does not Granger Cause ST_TR & $0.0977^{*}$ \\
\hline & & ST_TR does not Granger Cause RGDP & 0.4490 \\
\hline \multirow{2}{*}{ South Asia (Sas) } & \multirow{2}{*}{1} & RGDP does not Granger Cause ST_TR & 0.7270 \\
\hline & & ST_TR does not Granger Cause RGDP & 0.9606 \\
\hline \multirow{2}{*}{ Sub-Saharan Africa (Ssa) } & \multirow[b]{2}{*}{2} & RGDP does not Granger Cause ST_TR & $\mathbf{0 . 0 2 5 0}$ \\
\hline & & ST_TR does not Granger Cause RGDP & $0.0590 *$ \\
\hline
\end{tabular}

*significant at the $10 \%$ level.

Source: own calculations based on World Bank data. 
Borlea S.N., Mare C., Achim M.V., Puscas A. (2016)

Direction of causality between financial development and economic growth. Evidence for developing countries

\section{Conclusions}

The origin of financial development and economic growth nexus goes back to the work of Schumpeter (1934). In our study we intend to clarify which is the type of the relationship between different indicators of the financial market and the economic development for the developing countries which belong to various regions in the world. We used annual data provided by World Development Indicators (World Bank) over the period 1988 - 2011.

Depending on the financial indicator considered, the results obtained through this analysis come under one of the five groups of relationships emphasized in the literature. There are regions in which there are correlations between the financial markets and the economic development level, but there are also regions in which there is no connection between the two, neither in the short and medium term, nor in the long term. However, regardless of the financial indicator used, the strongest correlation between the financial market and economic development was found for the developing countries in the Sub-Saharan Africa. In two of the three cases assessed, the two markets are contemporaneously correlated, meaning that any change in the growth rate of the GDP will be felt immediately and strongly in the evolution of the financial market. Based on the Granger causality method, market capitalization on the long term is a cause for economic growth in the case of six out of the ten regions studied, but the reverse was not validated. When considering the stocks traded, we determined that, for some regions, financial development causes economic growth; for others, economic growth causes financial development. However, for others (the European Union and Sub-Saharan Africa in the third type of analysis), there is a two-way relationship between economic growth and capital market development.

The study may have policy implications for the national or international decisionmakers in order to acknowledge the real drivers of development for a country or for a region and helping for adopting the appropriate policies of growth.

As a limit of our study we can mention the fact that we include in the "financial development" only the stock market dimension of development, having in mind the financing from the stock market. We do not count on the financing from banks thus we do not include the bank dimension of development. In future studies we intend to extend our analysis with the bank dimension of the financial development.

\section{References}

1. Acaravci, A., Ozturk, I., Acaravci, S.K. (2007) Finance - Growth Nexus: Evidence from Turkey, Working Paper Series, April 30.

Studia Universitatis "Vasile Goldis" Arad. Economics Series Vol 26 Issue 2/2016 ISSN: 1584-2339; (online) ISSN: 2285 - 3065.

Web: publicatii.uvvg.ro/index.php/studiaeconomia.Pages $1-22$ 
Borlea S.N., Mare C., Achim M.V., Puscas A. (2016)

Direction of causality between financial development and economic growth. Evidence for developing countries

2. Ardic, O.P., Damar, H. E. (2006) Financial Sector Deepening and Economic Growth: Evidence From Turkey,Working Papers 2006/19, Bogazici University, Department of Economics.

3. Arestis P, Panicos O. D., Kul, B. L. (2001) Financial Development and Economic Growth: The Role of Stock Markets, Journal of Money, Credit and Banking, 33(1), 16-41.

4. Atje, R., Jovanovic, B. (1993) Stock Markets and Development, European Economic Review, 37, 632-64

5. Aslan, A., Gör. Ö., Kucukaksoy, İ. (2006) Finansal Gelisme ve Ekonomik Buyume Iliskisi: Turkiye Ekonomisi Uzerine Ekonometrik bir Uygulama, Ekonometri ve Istatistik 4, 12-28.

6. Baier, S., Dwyer, G.P.,Tamura, R. (2004) Does Opening a Stock Exchange Increase Economic Growth?, Journal of International Money and Finance, 23(3). 311-331.

7. Beck, T., Levine, R. (2004) Stock Markets, Banks and Growth: Panel Evidence, Journal of Banking and Finance, 28(3), 423-442

8. Beck, T., Lundberg, M.,Majnoni, G. (2006) Financial intermediary development and growth volatility: do intermediaries dampenor magify shocks ?, Journal of International Money and Finance, 25, 1146-1167.

9. Boubakari , A., Jin, D. (2010) The Role of Stock Market Development in Economic Growth: Evidence, from Some Euronext Countries, International Journal of Financial Research 1(1), 14-20.

10. Brasoveanu-Obreja, L., Dragota, V.,Catarama, D., Semenescu, A. (2008) Correlation between capital market development and economic growth: the case of Romania, Journal of applied quantitative methods, 3(1), 64-75.

11. Calderon, C., Liu, L. (2003) The Direction of Causality between Financial Development and Economic Growth, Journal of Development Economics, 72, 321-34

12. Caporale, G.M., Howells, P., Soliman, A.M. (2005) Endogenous Growth Models and Stock Market Development: Evidence from Four Countries, Review of Development Economics, 9(2), 2005, 166-176

13. Caporale, G.M., Rault, C., Sova R., Sova, A. (2009) Financial Development and Economic Growth: Evidence from Ten New EU Members, Discussion paper, DIW Berlin German Institute for Economic Research Berlin.

14. Chang, T. (2002) Financial development and economic growth in Mainland China: a note on testing demand-following or supply-leading hypothesis, Applied Economics Letters, 2002, 9, 869-873.

15. Chung, S.K. Tai, S. (1999), Cointegration and causality between macroeconomic variables and stock market return, Global Finance Journal 10(1), 71-81.

16. Demirhan, E., Aydemir, O., Inkaya, A. (2011) The Direction of Causality between Financial Development and Economic Growth: Evidence from Turkey, International Journal of Management, 28 (1), 3-19.

17. Dumiter F.C., Todor S.P., (2014), Modeling the relationship between foreign direct investments and economic growth- evidence from Central and eastern European Countries, Studia Universitatis "Vasile Goldis" Arad Economics Series Vol 24 Issue 2/2014, p. 1-18.

20 DE GRUYTER OPEN
Studia Universitatis "Vasile Goldis" Arad. Economics Series Vol 26 Issue 2/2016 ISSN: 1584-2339; (online) ISSN: 2285 - 3065.

Web: publicatii.uvvg.ro/index.php/studiaeconomia.Pages $1-22$ 
Borlea S.N., Mare C., Achim M.V., Puscas A. (2016)

Direction of causality between financial development and economic growth. Evidence for developing countries

18. El-Wassal, K.A. (2005), Understanding the Growth in Emerging Stock Markets, Journal of Emerging Market Finance 4, 227-261.

19. Fama, E.F., (1991). Efficient capital market, Journal of Finance 46(5), 1575-1617.

20. Garretsen, H., Lensink, R., Sterken, E. (2004), Growth, financial development, societal norms and legal institutions, Journal of International Financial Markets, Institution and Money, 14(2), 165-183.

21. Ghirmay, T. (2004) Financial development and economic growth in Sub-Saharan African countries: evidence from time series analysis, African Development Review 16, 415 $-432$

22. Goldsmith, R.W. (1969) Financial Structure and Development, New Haven, CT: Yale University Press

23. Graff, M. (1999) Financial Development and Economic Growth: A New Empirical Analysis, Dresden Discussion Papers in Economics No. 5/99.

24. Hanousek, J., Filer, R. K. (1997) The relationship between Economic Factors and equity markets in Central Europe, Working paper Number 78, June 1997.

25. Herve, D.B.G., Shen, Y. (2011) Management of Stock Price and It Effect on Economic Growth: Case Study of West African Financial Markets, International Journal of Business and Management, 6( 2), 52-71

26. Hondroyiannis, G., Lazaretou, S. (2004) Inflation Persistence during Periods of Structural Change: An Assessment Using Greek Data, Working Papers Series, No. 370, June, Bank of Greece, 1-44.

27. Kar, M., Pentecost, E.J. (2000) Financial Development and Economic Growth in Turkey: Further Evidence on the Causality Issue, Economic Research Paper No. 00/27, 120

28. King, R. G., Levine, R. (1993) Finance and Growth: Schumpeter Might Be Right, The Quarterly Journal of Economics, MIT Press, 108(3), 717-37.

29. Levine, R., Zervos, S. (1996) Stock market development and long-run growth, World Bank Economic Review 10, 323-339.

30. Liang, Q., Teng, J.Z. (2006) Financial development and economic growth: Evidence from China, China Economic Review 17 395-411,

31. Mun, H. W., Siong, E. C., Long, B.S., Thing, T.C. (2008) Stock Market and Economic Growth in Malaysia: Causality Test, Asial Social Science, 4(4), 86-92

32. Naceur, S. B., Ghazouani, S., Omran, M. (2008) Does Stock Market Liberalization Spur Economic and Financial Development in the Mena Region?, Journal of Comparative Economics, 36, 673-693

33. Ndako, U. B. (2010) Stock markets, banks and economic growth: a time series evidence from South Africa, African Finance Journal, 12( 2) , 72-92

34. Pearce, D.K., Roley, V. V. (1988) Firms characteristics, unanticipated inflation, and stock return, Journal of Finance 43 (4), 965-981.

35. Rajan, R.G., Zingales, L. (1998) Financial dependence and growth, The American Economic Review 88, 559-586. 
Borlea S.N., Mare C., Achim M.V., Puscas A. (2016)

Direction of causality between financial development and economic growth. Evidence for developing countries

36. Rousseau, P.L., Sylla, R. (2001) Financial Systems, Economic Growth, and Globalization, NBER Working Paper No. 8323, June 2001, 1-51.

37. Rousseau, P.L.,Wachtel, P. (2009) What is Happening to the Impact of Financial Deepening on Economic Growth?, Working Papers 0915, Department of Economics, Vanderbilt University.

38. Rousseau, P.L., Wachtel, P. (2011) What Is Happening To The Impact Of Financial Deepening On Economic Growth?, Economic Inquiry, Western Economic Association International, vol. 49(1), pages 276-288, 01.

39. Schumpeter, J. (1934) The Theory of Economic Development, Cambridge, Mass.: Harvard University Press.

40. Seetanah, B., Ramessur, S.T., Rojid, S. (2009) Financial development and economic growth, New evidence from a sample of island economies, Journal of Economic Studies Vol. 36( 2), 124-134.

41. Stiglitz, J. (2002) Participation and Development: Perspectives from the Comprehensive Development Paradigm, Review of Development Economy, Volume 6, Issue 2, 163-182, June 2002

42. Unalmis, D. (2002) The Causality Between Financial Development and Economic Growth: The Case of Turkey, Working Papers 0203, Research and Monetary Policy Department, Central Bank of the Republic of Turkey.

43. Van Nieuwerburgh, S., Buelens, F., Cuyvers, L. (2006) Stock market development and economic growth in Belgium, Explorations in Economic History, 43, 13-38.

44. Yay, G., Oktayer, A. (2009) Financial Development and Economic Growth - A Comparative Analysis, Romanian Journal of Economic Forecasting, 11(3), 56-74.

45. Wachtel, P. (2001) Growth and Finance: What Do We Know and How Do We Know It? International Finance, 4(3), 335-362.

46. Wong, A., Zhou, X. (2011) Development of Financial Market and Economic Growth: Review of Hong Kong, China, Japan, The United States and The United Kingdom, International Journal of Economics and Finance, 3( 2), 111-115.

47. Zivengwa, T. Mashika, J., Bokosi, F. K., Makova, T. (2011) Stock Market Development and Economic Growth in Zimbabwe, International Journal of Economics and Finance, 3(5), October, 140-150

48. World Bank (2012) World Development Indicators. World Bank, Washington, DC.

22 DE GRUYTER OPEN
Studia Universitatis "Vasile Goldis" Arad. Economics Series Vol 26 Issue 2/2016

ISSN: 1584-2339; (online) ISSN: 2285 - 3065.

Web: publicatii.uvvg.ro/index.php/studiaeconomia.Pages $1-22$ 